\title{
THE ANC AFTER THE 2004 ELECTION
}

\author{
By \\ Tom Lodge
}

Tom Lodge is a professor in the Department of Political Studies

at the University of the Witwatersrand

P O Wits 2050 Johannesburg South Africa

Tel: +27(0)11 717.4369; Fax: +27(0)11 403.7482

e-mail: lodget@social.wits.ac.za

\begin{abstract}
In the 2004 election the ANC obtained a larger share of the vote than ever beforenearly 70 per cent. About 200000 more people voted for it than had in 1999, despite a decline in overall turnout. In 2004, the ANC's gains were concentrated chiefly in the Transkei, in the Western Cape and in rural KwaZulu-Natal. It obtained more than 270000 fewer votes in Gauteng, though, despite a likely increase of about 20 per cent in the population of the province. These statistics are revealing because they offer useful indications of the ways in which the ANC has changed since its accession to power. Moreover, as the ANC's political base shifts geographically and alters sociologically, we can also discern trends that may offer pointers to the party's future.
\end{abstract}

\section{ConteXtuAL BACKGROUND}

The ANC was a mass-based liberation movement from the 1940s onwards, with its following concentrated in cities, amongst the most urbanised groups within the African population. The organisation's three centres of strength were on the East Rand (and to a lesser extent Johannesburg), in Durban and in Port Elizabeth. During the 1950s to a very large extent the organisation was built around a burgeoning trade union movement - in Port Elizabeth and on the East Rand, especially, local leadership was concentrated in the hands of trade unionists. In its social composition the ANC was essentially a workers' movement and this fact had an impact on its values and ideas. Marxism influenced even non-communists within the ANC's leadership (Nelson Mandela was one of them). With its adoption of the Freedom Charter in 1956, the ANC embraced a programme that envisaged substantive social reform, including the expansion of public ownership and land redistribution.

These trends continued in exile. Increasingly the ANC projected itself as a revolutionary movement, and a constituent in a wider movement of 'transition to the socialist system', to cite the policy statement it adopted at Morogoro in 1969. When the organisation was once more capable of building clandestine networks within South Africa, its main bases were again in the townships of Gauteng, in 
Durban, and in Port Elizabeth and East London. These vicinities supplied the main arenas for guerilla operations during the 1980s. Then, to use the words of Steve Tshwete, the working class constituted 'the backbone of the struggle' (Suttner \& Cronin 1986, p 212). Meanwhile, leading exponents of 'Charterist' politics argued 'that any programme to end racial oppression ... has to attack the key power centres of capitalism with which racial oppression is so interlocked' (Suttner \& Cronin 1986, p 29). Most township participants in 'struggle politics' saw themselves as engaged in a movement that, if victorious, would change social and economic arrangements very profoundly indeed.

\section{Contemporary Political Trends Within the ANC}

Today the ANC presides over a robust capitalist democracy. If anything, the private economic sector is stronger than ever as a consequence of privatisation and market liberalisation. Senior ANC leaders enjoy increasingly close connections with business, as even a cursory glance at the parliamentary register of private interests will reveal. Entrepreneurial undertakings by husbands and wives of politicians tighten the links between politics and boardrooms even further. Many of the struggle leaders of the 1980s have now become extremely wealthy. The ANC in government finds itself at odds with its former allies in the trade union movement (as well as, to an extent, the Communist Party) over aspects of foreign affairs, over macro-economic policy, and over land reform. More significantly, in relative terms, the ANC feels electorally most vulnerable in the former heartlands of its historic support, in the townships of Gauteng and elsewhere. Here significant numbers of working class citizens prefer to stay at home rather than vote. A battery of new protest movements hope to convert dissatisfaction with the performance of municipal councils into support for a Left alternative to the ANC. Meanwhile, the ANC's electoral strength is more and more concentrated in the countryside amongst the poorest and most marginalised. Those who approve most strongly of the Government's performance are most likely to be living in rural areas and to be recipients of pensions, disability grants and other kinds of welfare payments. Their numbers have quadrupled since 1994.

How do we explain these changes? Of course, to an extent, the ANC's choices in government have been circumscribed by the imperatives of the global economy as well as by the constitutional restraints that governed its accession to power. But neither of these factors explains the enthusiasm of the embrace of entrepreneurial values demonstrated by many ANC leaders. Contributing to the ANC's transformation is the inevitable alteration in its relationship with society that is a consequence of power. The party - or at least its leaders - can now allocate resources, and, in the countryside (though not to the same degree in the cities), patronage can command loyalty, particularly in those communities in which political values are still conservative and patrimonial.

An illustration of such power was the abuse of the social grants system cited at the end of 2004 by the Minister of Social Development, Zola Skewyiya. In several 
small towns in southern KwaZulu-Natal disability grants were being distributed to supporters of local political personalities through committees those personalities had constituted: as a consequence, several districts were registering implausibly high numbers of beneficiaries of such grants.

In the former 'homelands', when the ANC reconstructed itself during the early 1990s, its rapid political ascendancy was a result of an alliance with local notables, chiefs and bureaucrats, former subalterns of the apartheid regime. For a time at least, the former rulers and leading bureaucrats of at least five homelands - Transkei, Venda, Lebowa, KaNgwane and KwaNdebele - assumed prominent positions in regional ANC hierarchies. The venality of several provincial administrations, notably that of Mpumalanga, is a legacy of this deft transitional ploy.

The implications of the ANC's shift to becoming the major component in an electoral party system deserve more elaboration than they have received in most commentaries. ANC spokespeople continue to insist that the ANC remains a liberation movement and has yet to become an ordinary political party. In making such protestations they have two concerns. One is that, in their perception, parties in a parliamentary political system are socially partial, in other words, they represent relatively narrow social interests, whereas the ANC's history continues to constitute it as a broad nationalist coalition of groups that would normally find themselves in opposition in a party system (Jordan 1997). This position is not especially persuasive; in many well-established liberal democracies many parties attempt to represent, and even succeed in representing, a broad range of interests, even across major class divisions. Political organisations in the United States are good examples of 'catch-all' parties, as is the Congress Party in India.

The second strand in the ANC's continued assertion of its status as a liberation movement is that the organisation attempts to accomplish a wider range of political functions than simply those of interest and electoral representation; in this vein it points to the mobilising role that parties may perform in the service of developmental projects, as well as to its continued capacity to inspire and incubate protest movements locally, and even nationally - with respect to the latter, the Treatment Action Campaign, whose leaders emphasise their political affiliation to the ANC, would be a case in point. Here its claims to being rather more than a conventional electorally oriented political organisation are more credible.

But while ANC leaders may genuinely feel that their 'liberation' tasks remain incomplete, that even in power they continue to belong to a revolutionary movement, such claims should not divert attention from what changed in 1994. In the immediate period before the 1994 election and in the years that followed it, the ANC developed what it could never accomplish before: a national organisation with a structured, disciplined following of activists and officials in every significant population centre; in the countryside as well as in the cities. This organisation is partly sustained, as was the case with the ANC historically, by voluntary commitment, but, and this is the contrast with the ANC's previous history, it is also the effect of power, the capacity for patronage, and control over public resources. 
Arguably, with the acquisition of vast new rural/small town constituencies the earlier sources of political radicalism among followers of the ANC, in particular those resulting from its alliances with working class organisations, became much less influential. The ruralisation of the ANC's following may also help to strengthen patrimonial kinds of leadership and weaken the influence of those democratic norms introduced during the 1980s into the 'mass democratic movement' by trade union officials. Inkatha's poor showing in the 2004 poll, as well as its evident inability to find a successor to its founder, once again opens up the possibility of its absorption into ANC ranks. Such a development would certainly expand the role of patronclient politics in the ANC's KwaZulu-Natal organisation.

Social changes have also helped to shift the ANC away from its Jacobin traditions. During the 1990s the South African middle class - white-collar workers, professionals, technicians, managers and businessmen - became more black than white, and this group has become a vital source of political support. Social stability in South Africa both today and in the future will depend on the government's ability to continue, through its distribution of public goods, to improve the lives of the very poor, while at the same time expanding opportunities for the black middle class. Above inflation-rate wages and protection for existing jobs will keep the labour movement more or less on side, but essentially the ANC's political predominance depends on its near hegemonic appeal amongst middle-class black South Africans and the homage it receives from the rural poor.

Does this mean that the much-heralded split between African nationalism and labour is about to happen? This would be more likely if the ANC were in a state of organisational decay. In fact, though, the movement maintains a vigorous inner life, in the cities as well as the countryside, supported by expanding inflows of funds from local business. A survey undertaken at the end of 2002 by the Political Studies Department of the University of the Witwatersrand, in which students interviewed 500 or so branch members, mainly in Gauteng, showed that the organisation continues to maintain a culture of local activism and remains capable of extracting idealistic commitment from its membership. The latter was evident during 2002 and 2003 in the enthusiastic responses from many branches to President Mbeki's appeals to ANC followers to participate in voluntary development activities (Letsame). The survey cited above revealed that about 70 per cent of Gauteng respondents had taken part in Letsame activities: cleaning up public buildings and repairing schools, visiting AIDS patients, organising sports days, and so forth ${ }^{1}$. At this level the ANC continues to resemble a social movement rather than an electoral machine. Urban working-class ANC members are extremely likely to be trade union members and, as such, are as likely to defend the nationalist-labour alliance. As one acute observer noted in 2002, speeches by trade unionists at regional Cosatu meetings indicated 'the lower one moves down the hierarchy [in trade unions] the

$1 \quad$ For more detail see Lodge 2004, pp 194-196. 
more direct the felt connection with the ANC' (Forrest 2002). It is, however, a misconception that the ANC depends on trade unions to 'deliver' its urban constituency at the polling stations. When trade unionists are active as party canvassers their activism is an expression of their involvement in a lively culture of local political life, not a response to the injunctions of shop stewards.

To be sure, the ANC would rather not lose the loyalty of trade union officials - a trade union sponsored opposition would certainly draw some support from its base - but it is quite conceivable that the ANC could win an election without formally expressed trade union support. The continuing trend, evident in 2004, of the ANC's most steadfast adherents becoming increasingly rural will certainly influence relationships between the party and its historical allies. It is already doing so - the increasing assertiveness of the ANC Youth League (ANCYL) leadership is a consequence of this stage. The league claims to have 500000 members, predominantly drawn from unemployed rural school leavers. In the last few months the leadership of the league has been sharply at odds with the Congress of South African Trade Unions (Cosatu) over the latter's efforts to defend civil liberties in Zimbabwe, and with the ANC Women's League, with respect to the issue of succession to the leadership of the ANC.

Youth League officials support Robert Mugabe's land seizures and deride the Zimbabwean president's opponents and critics as local proxies for Western powers. The league has also emerged as the champion of Deputy President Jacob Zuma's aspirations to ascend to the presidency: there should be no debate about this forthcoming development, leaguers insist, for such an appointment would conform with previous ANC practice (Ndlangisa 2005). Both positions are probably genuinely popular with the league's rural supporters (radical land reform on the Zimbabwe model finds little support in cities (Mannak 2004).

The Youth League's assertiveness is also an expression of its relatively independent financial status, a consequence of a sequence of lucrative 'empowerment' arrangements which include a close association between the league's Lembede Investment Holdings and Johannesburg Consolidated Investment's (JCI) main shareholder, Brett Kebble. During 1994, Lembede, together with two other well connected empowerment groups, purchased a R1,5-million asset portfolio from JCI (Deane 2005). Brett Kebble's and the leaguers' business undertakings have attracted unwelcome attention from both the press and the National Prosecutions Authority's [NPA] Scorpions and the Youth League's hostility towards the NPA's investigation of corruption allegations against Zuma was hardly disinterested.

\section{ENTRENCHMENT OF THE DOMINANT-PARTy SYNDROME}

Within South African political analysis it has almost become conventional to portray the country's democracy as curtailed by a dominant party. From this perspective the ruling party itself is perceived as becoming increasingly hierarchical and 
centralised, with power concentrated in its leadership². Such beliefs are buttressed by the Leninist organisational language and phraseology sometimes employed by ANC leaders. In reality, however, the ANC's organisational expansion during the 1990s may have made the party more difficult to manage and may have increased its susceptibility to division and, even, internal challenges to authority. For what ANC leaders call factionalism is partly a consequence of the movement's geographical spread as well as its reconstitution over the dispersed centres of power represented by provincial governments ${ }^{3}$ and municipalities, both crucial and often lucrative sources of patronage and business empowerment for ANC notables and their kinsfolk and associates.

Significantly, modern ANC factions seldom appear to be animated by formal ideological or programmatic differences with central or more senior ANC leaders; rather the fault-lines that separate the factions appear to be the effect of regional identities, as in the Free State provincial ANC, or ethnic jealousies, as in Limpopo, the latter making a reappearance in ANC social life after a long absence since the 1930s. Interestingly, the Youth League's support for Jacob Zuma's candidacy for the movement's presidency appears to have little to do with ideology: up to now Zuma has normally been associated with the left wing of the organisation and, indeed, in any bid for the presidency would probably enjoy the backing of many trade unionists. Jacob Zuma's political ascendancy would probably represent a setback for 'neo-liberal' party modernisers grouped around the current presidency and would signify a triumph for rank and file assertion within the organisation. Zuma is undoubtedly popular with party activists, not least because of his own presentation of himself as a Zulu 'traditionalist' commoner.

Electoral advances, even past the symbolically important level of two-thirds support (which theoretically increases leadership discretion to enact constitutional alterations), do not translate into corresponding increments in leadership authority. Public policy of successive ANC governments has been shaped to a much greater degree by the sociology of the movement in power than its critics recognise. The most striking characteristic of South African government policy and performance is not the presidency's commitment to the modern conventions of market oriented macroeconomic public management, steadfast as this is. The importation of business models into public affairs is now routine internationally. As we have seen also, here they reflect the new intimacy between African nationalism and business that can be expected as a consequence of the nurturing of black business through racially preferential state procurement.

What is remarkable, though, is the retention and expansion of the state's commitment to welfare, especially with respect to provision of pensions (unusually generous by any reasonable international comparisons), disability grants and child

2 For arguments in this direction see the concluding chapter in Giliomee and Simkins 1999.

3 For a useful discussion of provincial politics during the Mandela administration see Hawker 2000, pp 631-58. 
support (see Seekings 2002, especially pp 1-5). In general, welfare budgets account for more than half the Government's expenditure and have been increasing proportionately. Such commitments are not necessarily a consequence of the influence on the ANC of organised labour: government has been more than ready to confront labour over foreign trade policies that have caused considerable job losses. It makes more sense to view the massive expansion of welfare provision assiduously encouraged by political leadership - as an effect of the ANC's incorporation of the countryside into its political domain.

More widely, since 1994 government resource allocation has demonstrated a bias towards the countryside, a predisposition that can only be strengthened and confirmed by the 2004 election results, and a reflection of the ANC's continued susceptibility to social pressure from its support base. The apparent shift in government strategy with respect to the future of the remaining parastatal corporations, in which they are likely to remain substantially publicly owned, is probably a response to broad developmental imperatives - in particular the extension of rurally located 'infrastructure' - rather than a concession to trade union antipathy to privatisation. The evidently stronger commitment to land reform signalled by a doubling of the budgetary allocation this year - is a striking expression of the growing influence of the ANC's rural following.

The other feature of government policy which is singular and certainly differentiates it from the laissez-faire conventions of neo-liberal governance is the prominent status assigned to black empowerment measures by Thabo Mbeki's administration, particularly since the passage of the Black Economic Empowerment Act at the beginning of 1994. An official 'scorecard' that balances different aspects of empowerment, including black participation in ownership and management, has prompted the development of a range of 'charters' defining empowerment targets for different industries. This is likely to stimulate an unprecedented degree of state and public agency regulation of the internal operations of the private sector. Strengthening likely state commitment to the achievement of empowerment targets is the degree to which former political leaders and senior civil servants, as well as the families and associates of present political leadership, have been beneficiaries of empowerment transactions in which new black-owned companies have acquired substantial stakes in established industrial concerns. Such developments are likely, incidentally, to increase the flow of funding from South African business to the ruling party, which, until the present, has remained heavily dependent on foreign donations.

\section{BEYOND THE 2004 ELECTION}

In these areas it is reasonable to expect continuity in the next few years. A more populist presidential style after 2007 , the year the ANC is expected to elect its new leadership, might not guarantee comparable commitment to other current policy positions, especially those that command only weak public support. A recent series 
of political attacks on the judiciary and judicial agencies such as the NPA by ANC officials and parliamentarians probably accords with wider public predispositions: the justice system still lacks legitimacy and this continues to render the Constitution vulnerable. Opinion polls register higher levels of mistrust in the courts than in any other public institution (including Parliament and local government) except for the police (See, for examples, Rule 2000, p 58 and Mattes, Davids and Africa, p 34). To date, it must be said, South African political leadership has generally honoured its constitutional obligations, even when judges have found its proposed laws and policies to be unconstitutional, as when the courts compelled the government to expand the provision of anti-retroviral medication to HIV / AIDS patients.

In a context, though, in which powerful political personalities find themselves more deeply at odds with legal agencies, as has been the case with Jacob Zuma, procedural democracy might be tested very severely indeed. One of the distinctive features of Thabo Mbeki's presidency has been its evident commitment to leadership renewal. Ten members of Mbeki's new Cabinet after the 2004 election were fresh appointments to ministerial office. Only eleven members had held office under Mandela. In a Cabinet composed of men and women whose political apprenticeship was served mainly during the 1980s and 1990s most of the architects of South Africa's constitutional democracy, those with a personal stake in its maintenance, have long since departed.

\section{- REFERENCES -}

Deane, Nawaal. 2005. 'Young lions at it again'. Mail \& Guardian 28 January.

Forrest, Drew. 2002. 'A bond not easily broken', quoting Jane Barrett, a transport trade union official. Mail \& Guardian 1 February.

Giliomee, Hermann and Charles Simkins (eds). 1999. The Awkward Embrace: One Party-Domination and Democracy. Cape Town: Tafelberg.

Hawker, Geoffrey. 2000. 'Political Leadership in the ANC: The South African Provinces 1994-1999'. Journal of Modern African Studies 38(4).

Jordan, Pallo. 1997. 'ANC owes a debt to history - and to its people'. Star 8 January. Lodge, Tom. 2004. 'The ANC and the Achievement of Party Politics in Modern South Africa'. Journal of Modern African Studies 42(2).

Mannak, Miriam. 2004. 'Zim-style land reform has little backing here - survey'. Star 24 November.

Mattes, Robert, Yul Derek Davids and Cherrel Africa. 2000. 'Views of Democracy in South Africa and the Region'. Afrobarometer Paper No 8. Cape Town: Institute for Democracy in South Africa (Idasa), October.

Ndlangisa, Sabelo. 2005. 'From king-makers to party hacks'. Sunday Times 9 January. Rule, Stephen (ed). 2000. Public Opinion on National Priority Issues. Pretoria: Human Sciences Research Council, March. 
Seekings, Jeremy. 2002. 'The Broader Importance of Welfare Reform in South Africa'. Social Dynamics 28(2).

Suttner, Raymond and Jeremy Cronin. 1986. 30 Years of the Freedom Charter. Johannesburg: Ravan Press. 